\title{
The effects of hip- and ankle-focused exercise intervention on dynamic knee valgus: a systematic review
}

\author{
Farhah Nadhirah Aiman Sahabuddin ${ }^{1}$, Nazatul Izzati Jamaludin ${ }^{1}$, Nurul Hidayah Amir ${ }^{2,3}$, Shazlin Shaharudin ${ }^{\text {Corresp. }}$ \\ ${ }^{1}$ Exercise and Sports Science Programme, School of Health Sciences, Universiti Sains Malaysia, Kota Bharu, Kelantan, Malaysia \\ 2 Department of Translational Health Sciences, Faculty of Health Science, University of Bristol, Bristol, United Kingdom \\ 3 Faculty of Sports Science and Recreation, Universiti Teknologi MARA, Arau, Perlis, Malaysia \\ Corresponding Author: Shazlin Shaharudin \\ Email address: shazlin@usm.my
}

Background. A range of non-contact injuries such as anterior cruciate ligament tear, patellar displacement and patellofemoral pain syndrome are caused by disordered knee joint loading from excessive dynamic knee valgus (DKV). Previous systematic reviews showed that DKV could be modified through the influence of hip strength and ankle range of motion. There was also a narrative review that investigated hip-focused neuromuscular exercise intervention on DKV. Therefore, the purpose of this systematic review was to examine the effects of exercise intervention which involved either top-down or bottom-up kinetic chains on minimizing DKV in male and female adults and adolescents, with and without existing knee pain. Methodology. Electronic searches were conducted in SAGE, Science Direct, SCOPUS, and Pubmed. The search strategy consisted of the medical subject headings and the free-text search keywords, synonyms and variations of 'exercise intervention,' 'knee alignment,' 'dynamic knee valgus', 'knee abduction' that were merged via the Boolean operator 'AND' and 'OR'. The search was conducted on full-text journals that documented the impact of the exercise intervention program involving either the bottom-up or top-down DKV mechanism on the knee kinematics. Furthermore, exercise intervention in this review should last at least one week which included two or three sessions per week. This review also considered both men and women of all ages with a healthy or symptomatic knee problem. The risk of bias of the included studies was assessed by Cochrane risk assessment tool. The protocol of this review was registered at PROSPERO (registration number: CRD42021219121). Results. Ten studies with a total of 289 participants (male $=122$, female $=321$; adults $=230$, adolescents $=142$; preadolescent $=51$ ) met the inclusion criteria were included in this review. Seven studies showed the significant effects of the exercise intervention program (range from two weeks to ten weeks) on reducing DKV. The exercise training in these seven studies focused on muscle grouns directly attached to the knee joint such as hamstrings and gastrocnemius.
Peerl revivewing PDF (2021:02:57678:2:0:NEW 25 May 2021) 
The remaining three studies did not show significant improvement in DKV after the exercise intervention (range between eight weeks to twelve weeks) probably because they focused on trunk and back muscles instead of muscles crossing the knee joint. Conclusion. Exercises targeting specific knee-joint muscles, either from top-down or bottom-up kinetic chain, are likely to reduce DKV formation. These results may assist athletes and coaches to develop effective exercise program that could minimize DKV and ultimately prevent lower limb injuries. 


\section{The effects of hip- and ankle-focused exercise}

\section{2 intervention on dynamic knee valgus: a systematic}

3 review

4

5 Farhah Nadhirah Aiman Sahabuddin ${ }^{1}$, Nazatul Izzati Jamaludin ${ }^{1}$, Nurul Hidayah Amir ${ }^{2,3}$, Shazlin

6 Shaharudin ${ }^{1}$

7

$8{ }^{1}$ Exercise and Sports Science Programme, School of Health Sciences, Universiti Sains Malaysia,

9 Kota Bharu, Kelantan, Malaysia

10 2Department of Translational Health Sciences, Faculty of Health Science, University of Bristol,

11 Bristol, United Kingdom

$12{ }^{3}$ Faculty of Sports Science and Recreation, Universiti Teknologi MARA, Arau, Perlis, Malaysia 13

14 Corresponding Author:

15 Shazlin Shaharudin

16 Exercise \& Sports Science Programme,

17 School of Health Sciences,

18 Universiti Sains Malaysia,

1916150 Kubang Kerian, Kelantan

20 Email address: shazlin@usm.my 


\section{Abstract}

23 Background. A range of non-contact injuries such as anterior cruciate ligament tear, patellar displacement and patellofemoral pain syndrome are caused by disordered knee joint loading from excessive dynamic knee valgus (DKV). Previous systematic reviews showed that DKV could be modified through the influence of hip strength and ankle range of motion. There was also a narrative review that investigated hip-focused neuromuscular exercise intervention on DKV. Therefore, the purpose of this systematic review was to examine the effects of exercise intervention which involved either top-down or bottom-up kinetic chains on minimizing DKV in male and female adults and adolescents, with and without existing knee pain.

Methodology. Electronic searches were conducted in SAGE, Science Direct, SCOPUS, and Pubmed. The search strategy consisted of the medical subject headings and the free-text search keywords, synonyms and variations of 'exercise intervention,' 'knee alignment,' 'dynamic knee valgus', 'knee abduction' that were merged via the Boolean operator 'AND' and 'OR'. The search was conducted on full-text journals that documented the impact of the exercise intervention program involving either the bottom-up or top-down DKV mechanism on the knee kinematics. Furthermore, exercise intervention in this review should last at least one week which included two or three sessions per week. This review also considered both men and women of all ages with a healthy or symptomatic knee problem. The risk of bias of the included studies was assessed by Cochrane risk assessment tool. The protocol of this review was registered at PROSPERO (registration number: CRD42021219121).

Results. Ten studies with a total of 289 participants $($ male $=122$, female $=321$; adults $=230$, adolescents $=142$; pre-adolescent $=51$ ) met the inclusion criteria were included in this review. Seven studies showed the significant effects of the exercise intervention program (range from two weeks to ten weeks) on reducing DKV. The exercise training in these seven studies focused on muscle groups directly attached to the knee joint such as hamstrings and gastrocnemius. The remaining three studies did not show significant improvement in DKV after the exercise intervention (range between eight weeks to twelve weeks) probably because they focused on trunk and back muscles instead of muscles crossing the knee joint.

Conclusion. Exercises targeting specific knee-joint muscles, either from top-down or bottom-up kinetic chain, are likely to reduce DKV formation. These results may assist athletes and coaches to develop effective exercise program that could minimize DKV and ultimately prevent lower limb injuries.

Keywords: biomechanics, kinetic chain, knee alignment, strength training 


\section{Introduction}

Dynamic knee valgus (DKV) is defined as a body position in which the knee collapses from excessive valgus, excessive internal-external rotation, or both conditions (Krosshaug et al., 2007). DKV can be caused by hip abductor weakness that entails internal rotation of the hip, excessive frontal knee alignment or tibial rotation angles and contralateral pelvic drop (Powers, 2010). Disordered knee joint loading from excessive DKV can trigger a spectrum of injuries such as anterior cruciate ligament (ACL) tear, patellar displacement, and patellofemoral pain (Myer et al., 2015).

Two types of kinetic chains play a major role in the mechanisms of DKV, namely topdown (proximal origin) and bottom-up (distal origin) kinetic chains (Jamaludin et al., 2020). A top-down kinetic chain occurs when the hip and trunk muscles alter the distal joints' kinematic patterns (Snyder et al., 2009). On the contrary, a bottom-up kinetic chain involves the influence of ankle musculature and foot structures on knee joint motions (Khamis \& Yizhar, 2007). Several studies have reported that the strength of hip adduction, knee flexion, and knee extension were the key indicators of knee valgus (top-down kinetic chain) (Willson et al., 2011; Willson, Ireland \& Davis, 2006). Besides, recent studies also observed that excessive DKV could be associated with foot-ankle strength as well as its range of motion (ROM) and kinematics (bottom-up kinetic chain) (Kagaya, Fujii \& Nishizono, 2015; Lima et al., 2018). Previous studies aimed to find the sources of excessive DKV and knee joint loading to prevent lower extremity injuries such as ACL strain (Nessler, Denney \& Sampley, 2017). Several other studies also presented evidence on how preventive training programs could minimize the occurrence of noncontact lower extremity (Petersen et al., 2005), knee or ACL (Hewett et al., 1999), and ankle injuries (Verhagen et al., 2004).

A systematic review by Lima et al. (2018) evaluated the association between ankle dorsiflexion (bottom-up kinetic chain) and DKV in interventional and non-interventional studies. By including the non-interventional studies, the review results might not be related to the impact of exercises on reducing DKV. Meanwhile, a systematic review by Dix et al. (2018) investigated the association between hip muscle strength (top-down kinetic chain) and DKV in asymptomatic (i.e., free from any injury) females. Similarly, the review did not investigate the effects of exercises that contribute to hip muscle strength in reducing DKV. A narrative review by Ford et al. (2015) provided details on a hip-focused neuromuscular exercise intervention to improve DKV. However, narrative review by Ford et al., (2015) excluded in-depth and systematic literature search approach, hence it may miss out several relevant papers. The review with metaanalysis conducted by Lopes et al., (2018) was focused on the effects of injury prevention programs (IPPs) specifically on landing biomechanics as they relate to the ligament, quadriceps, trunk, and leg dominance theories of ACL injury. To the best of our knowledge, no systematic review has been conducted that focused on the effects of top-down (hip-focused) or bottom-up (ankle-focused) kinetic chain of exercise intervention on DKV mechanisms. The review will shed light on how the exercise training programs may improve the mechanisms behind knee 
97 injury. Therefore, the present systematic review aims to determine the influence of hip- and 98 ankle-focused exercise intervention on improving DKV.

\section{Methods}

101

102

103

104

105

106

107

108

109

110

111

112

113

114

115

116

117

118

119

120

121

122
This review was conducted in compliance with the recommendations of the Preferred Reporting Items for Systematic Reviews (PRISMA) (Liberati et al., 2009). Universiti Sains Malaysia granted ethical approval to carry out the study within its facilities (Ethical Application Ref: USM/JEPeM/18070316). The protocol of this review was registered at PROSPERO (registration number: CRD42021219121).

Search Strategy

Two researchers (FNAS and NIJ) individually screened through four medical databases, namely SCOPUS, SAGE, Pubmed, and Science Direct from database inception until November 2020. The search technique consisted of medical subject headings (MeSH) and free text search keywords, synonyms, and variations to retrieve all relevant articles. Three phrases were merged for searching databases using the Boolean operator 'AND' and 'OR': i.e. 'exercise intervention,' 'training', 'knee alignment,' 'dynamic knee valgus', 'knee abduction'. The reference lists of all the included manuscripts and authors' files were also reviewed to identify other relevant studies.

Study Selection

The titles and abstracts of the retrieved studies were downloaded into Mendeley (version 1.19.4, Mendeley, London, United Kingdom). Two independent reviewers scanned all abstracts for eligibility and removed any duplicates. Full texts were obtained for abstracts that fulfilled the inclusion criteria. In the event of any ambiguous details, the corresponding authors of the studies were contacted via e-mail. Any disagreement between the two investigators would be resolved by discussing with the third investigator (SS) so that a consensus could be reached. A schematic diagram of the study selection is shown in Figure 1.

$<<$ insert Figure 1 here $>>>$

\section{Inclusion and Exclusion Criteria}

To be eligible for inclusion, the studies must describe the impact of the exercise intervention program that involved either the bottom-up or the top-down DKV mechanism on the knee kinematics. The duration of the intervention must be at least one week with two or three sessions per week. Men and women of all ages with healthy or symptomatic knee conditions were included. There was no limitation on the date of publication. Only human interventional studies presented in English full-text journals that discussed DKV or knee alignment were included in this review. Other research designs such as meta-analyses, systematic reviews, case 
131 reports and series, cross-sectional studies, concept papers, editorials, opinions, and in vitro

132 research were excluded. Seminar, poster presentations, reviews, case studies, editorials, letters,

133 and abstract-only texts were also excluded.

134 Data Extraction

135 For every included study, two researchers extracted the information. The data were

136 synthesized and tabulated based on the first authors' surname, date of publication, sample size,

137 participants' age and fitness level, exercise intervention and its duration, group allocations,

138 methods of outcome assessment, functional tasks, and outcomes (Table 1).

$139<<<$ insert Table 1 here $>>>$

140

141 Quality Assessment

142 The methodological quality of the included studies was evaluated based on the Cochrane

143 risk bias assessment tool. The tool assessed random sequence generation, allocation

144 concealment, blinding of participants and personnel, blinding of outcome assessment, incomplete

145 outcome data, selective reporting, and other biases in the studies. Items were scored as "yes",

146 "no", or "unclear". The details of the analysis of the risk of bias are described in Figure 2.

$147<<<$ insert Figure 2 here $>>>$

148

149 Results

150 Characteristics of Included Studies

151 A total of 590 articles were identified in the database search, but only two were included

152 in the final review (Bell et al., 2013; Barendrecht et al., 2011). Additionally, thirteen other

153 potential papers were identified when manually checking the reference lists of the included

154 articles. Only eight fulfilled the inclusion criteria (Sheerin, Hume \& Whattman, 2012; Baldon et

155 al., 2014; Czasche et al., 2017; Araújo et al., 2017, McCurdy et al., 2012; Jeong et al., 2021;

156 Thompson-Kolesar et al., 2017 \& Saad et al., 2018). Therefore, a total of ten studies were included

157 in the final review.

158 In general, the results of included studies are differed based on the types of exercise

159 prescribed in the training program and the participants involved. Most studies focused on

160 strengthening the hamstring and quadriceps muscles. Only Bell et al., (2013) targeted the

161 improvement of the hip and ankle muscles' strength and flexibility. The duration and frequency of

162 exercise training program ranged from three to 12 weeks, with two to three sessions per week. The

163 participants in the included studies were volunteers (Bell et al., 2013), university students (Araújo

Peer] reviewing PDF | (2021:02:57678:2:0:NEW 25 May 2021) 
164 et al., 2017), handball players (Barendrecht et al., 2011), , young athletes (Sheerin, Hume \&

165 Whattman, 2012), recreational athletes (Czasche et al., 2017; Jeong et al., 2021), preadolescent

166 and adolescent soccer athletes (Thompson-Kolesar et al., 2017), females with previous athletic

167 experience (McCurdy et al., 2012) and patients with patellofemoral pain syndrome, PFPS (Baldon

168 et al., 2014; Saad et al., 2018). Six studies involved only women (Baldon et al., 2014; Saad et al.,

169 2018; Araújo et al., 2017; Czasche et al., 2017; McCurdy et al., 2012; Thompson-Kolesar et al.,

170 2017), one study included only men (Jeong et al., 2021) and the remaining studies included both

171 genders.

172 Regarding the study procedures, Czasche et al. (2017), Jeong et al., (2021) \& McCurdy et

173 al., (2012) did not mention any screening procedure used to evaluate excessive DKV. Moreover,

174 Baldon et al., (2014) and Saad et al., (2018) did not specify any screening procedure to evaluate

175 excessive DKV because they implied the presence of knee valgus based on the diagnosis of PFP

176 injury. However, other five studies, namely Barendrecht et al., (2011); Bell et al., (2013); Araújo

177 et al., (2017); Sheerin, Hume \& Whattman, (2012); Thompson-Kolesar et al., (2017), screened the

178 participants for excessive DKV through various types of test. Barendrecht et al., (2011) measured

179 knee valgus from the drop-jump test by evaluating the knee minimum distance values (i.e., less

180 than 49.96\% showed the presence of knee valgus) using 2-D analysis. Meanwhile, Bell et al.,

181 (2013) visually confirm the presence of knee valgus during double-legged squat (DLS) whereas,

182 Araújo et al., (2017) screened DKV during 18-cm step-down task. Sheerin, Hume \& Whattman

183 (2012) screened DKV based on the pre-running test's knee abduction angle while, Thompson-

184 Kolesar et al., (2017) evaluated baseline knee valgus angle and moments for double, single-legged

185 landing, preplanned and unanticipated cutting tasks.

186 The effectiveness of an exercise intervention program in improving DKV was evaluated

187 using a variety of tasks such as step-up and step-down (Saad et al., 2018; Araújo et al., 2017),

188 DLS (Bell et al., 2013), single-leg squat (Baldon et al., 2014), double, single-legged landing,

189 preplanned and unanticipated cutting (Thompson-Kolesar et al., 2017), side step cutting (Jjeong et

190 al., 2021), drop jump (Barendrecht et al., 2011), unilateral and bilateral landings (Czasche et al.,

191 2017), unilateral and bilateral drop jumps (McCurdy et al., 2012), and running analysis (Sheerin,

192 Hume \& Whattman, 2012). Our results showed that seven studies reported significant difference

193 in DKV following the exercise intervention program (Saad et al., 2018; Bell et al., 2013; Baldon et

194 al., 2014; Jeong et al., 2021; Thompson-Kolesar et al., 2017; Barendrecht et al., 2011; Sheerin,

195 Hume \& Whattman, 2012)). On the other hand, Czasche et al., (2017), Araújo et al., (2017) and

196 McCurdy et al., (2012) did not detect any significant improvement on DKV after the exercise

197 intervention program.

\section{Discussion}

199 Previous systematic reviews revealed the association of increased ankle dorsiflexion

200 ROM (i.e., bottom-up kinetic chain) and hip strength (i.e., top-down kinetic chain) in reducing

201 DKV (Lima et al., 2018; Dix et al., 2018). Additionally, a narrative review found that 
202 neuromuscular exercises targeting hip musculature strength may alter DKV (Ford et al., 2015).

203 However, to date, there is no systematic review investigating the impact of exercise intervention

204

205

206

207

208

209

210

211

212

213

214

215

216

217

218

219

220

221

222

223

224

225

226

227

228

229

230

231

232

233

234

235

236

237

238

239

240 based on top-down and bottom-up kinetic chains on DKV. We found that several exercise programs have successfully minimized excessive DKV in several tasks, for example, step-up and step-down (Saad et al., 2018), DLS (Bell et al., 2013), single leg squat (Baldon et al., 2014), double-legged landing (Thompson-Kolesar et al., 2017), drop jump (Barendrecht et al., 2011), side step cutting (Jeong et al., 2021) and running gait (Sheerin, Hume \& Whattman, 2012). However, some studies showed no changes on DKV particularly during unilateral and bilateral landings (Czasche et al., 2017), unilateral and bilateral drop jumps (McCurdy et al., 2012) and step-down task (Araújo et al., 2017) following exercise intervention programs.

Sheerin, Hume \& Whattman, (2012) observed that eight weeks of lower limb functional exercise program minimally altered the knee frontal plane motions during running. The study randomly assigned 19 youth athletes from a long-term athletic development program to either the control group that received only upper limb strengthening exercises or the experimental group that received both upper limb strengthening and lower limb functional exercises that focused on minimizing knee valgus angle. The experimental group performed functional weight bearing exercises aimed at reducing knee valgus angle and open and closed kinetic chain exercises to promote hip muscle activation. Thus, the exercises training involved a top-down kinetic chain that emphasized hip muscle to reduce knee valgus. The study was among the first to describe the effects of a lower limb functional exercise intervention on the running mechanics in the cohort of youth athletes. The minimal changes of knee valgus angle could be due to the studied population (i.e., youth athletes) who are accustomed to regular high-intensity training. Additionally, the study provided important insight on injury prevention as injury rates were often higher among youth athletes (Mail et al., 2019).

Barendrecht et al. (2011) showed that neuromuscular training resulted in greater contact time, knee valgus and knee flexion angles during a drop jump test. They divided 80 adolescent handball players into two groups that received either neuromuscular training (NMT) $(n=49)$ or regular training (RT) $(n=31)$. The exercises in the NMT group included a combination of topdown and bottom-up kinetic chain exercises that were focused on enhancing hamstrings muscular strength and ankle motion control to alter knee mechanics. Meanwhile, the RT group received only regular handball training. Following that, the participants were also grouped based on their knee minimum distance values measured during landing or take-off in a drop jump test (Noyes et al., 2005). By using a cut-off point of 49.96\%, those with knee minimum distance below the cut-off point value were assigned to the below-average valgus aligned (BAVA) group as compared to those in the above-average valgus aligned (AAVA) group (Barendrecht et al., 2011). The integrated NMT group displayed better knee kinematics and single-leg stability than RT, particularly among adolescent handball players with AAVA. Thus, it is recommended to incorporate the NMT program to improve knee valgus angle particularly among adolescent handball players between 13-16 years old who were predisposed to a high risk of ACL injury 
241 (Griffin et al., 2006). In fact, the overall rate of injury among this group of players was

242 comparable to those in the senior handball team (Olsen et al., 2006).

Thompson-Kolesar et al., (2017) investigated the effects of FIFA Medical and Research

244 Center (F-MARC) 111 injury prevention warm-up program on differences in biomechanical risk factors for ACL injury between pre-adolescent and adolescent female soccer playersEach age group was divided into two groups; intervention (received F-MARC 11+ injury prevention warm-up program in 15 sessions 7-8 weeks ( 2 sessions per week)) and control (did not received any program). The F-MARC 11+ involved exercises for core strength, neuromuscular control and balance, eccentric training of the hamstrings, plyometric and agility. The program involved a combination of top-down and bottom-up kinetic chain to alter the mechanisms of knee valgus formation as the exercises in the program focused on hip and ankle muscles. Then, the biomechanical changes were evaluated during four functional tasks; double-legged landing, single-legged landing, pre-planned and unanticipated cutting. The authors noted that the preadolescent athletes improved more in knee valgus angle and moment during the doublelegged jump than adolescent athletes, implying that they can gain more from participation in the F-MARC $11+$ program.

Bell et al., (2013) recruited a total of 32 volunteers with knee valgus before assigning them randomly to either the control or intervention group. Knee valgus was identified visually through the usage of corrected heel lift during a DLS. Bell, Padua \& Clark, (2008) mentioned that corrected heel lift during DLS might restrict certain ankle motion, especially ankle dorsiflexion associated with the bottom-up mechanism of DKV. If the midpoint of the patella moved medially to the great toe in three to five squats, the participants were identified as having knee valgus. The intervention program was comprised of hip- and ankle-focused muscle strengthening and ankle flexibility exercises for two to three weeks. Therefore, the intervention program used a combination of top-down and bottom-up kinetic chain to reduce knee valgus. As for the control group, they did not receive any exercise program throughout the intervention period. The intervention group showed a $64 \%$ reduction of knee valgus during squat compared to their baseline and the control group. The ankle strength and flexibility (i.e., bottom-up kinetic chain) may alter the individual's poor movement patterns by limiting medial knee displacement (MKD) and increasing the ankle dorsiflexion ROM during DLS (Bell et al., 2013). This is due to the ankle being placed in a more plantarflexed position, which reduced the knee abduction. The study by Bell et al., (2013) was among the first to demonstrate changes in the knee valgus angle during DLS following bottom-up DKV kinetic chain (i.e., ankle-focused) exercise intervention in individuals with identified knee valgus. However, it is crucial to highlight that the physical

275 activity level of the participants in this study was not assessed or controlled, which may have influenced the results. Moreover, fitness level and gender of participants may influence the outcomes of intervention. For instance, in a study by Mohd Azhar et al., (2019), no association of foot positions on lower limb kinematics during single leg squat (i.e., bottom-up kinetic chain)

279 among highly trained male youth athletes, although Ishida et al., found significant association of similar variables among sedentary females. 
Baldon et al., (2014) found that functional stabilization training (FST) consisted of hip muscle strengthening, lower limb and trunk movement control exercises (i.e., a combination of top-down and bottom-up kinetic chain exercises), modified the knee kinematics in the frontal plane during single leg squat (SLS). In this study, a total of 31 female recreational athletes with PFPS were assigned randomly to either standard training (ST) or FST group. The ST group received stretching, traditional weight-bearing and non-weight-bearing exercises that stressed on strengthening the quadriceps (i.e., top-down kinetic chain only). Although no DKV screening test was conducted by Baldon et al. (2014), PFPS was regularly associated with excessive DKV (Hewett et al., 2005). The study highlighted the contribution of FST towards improving the lower limb control on the frontal plane motion following 8-weeks of intervention. Nevertheless, this study's findings were only limited to females with PFPS (Baldon et al., 2014).

Jeong et al., (2021) reported that the intervention group showed reduced knee valgus during side-step cutting task following ten weeks of core strength training. This study involved 48 male participants who were assigned randomly to either the intervention or control group. The intervention group performed core muscles' exercises (i.e., top-down kinetic chain) for ten weeks with three sessions per week while the control group continued their daily routine. The results corroborate the findings of Willson et al., (2006), who discovered that participants with greater isometric core strength had reduced knee valgus angles during SLS. Jeong et al., (2021) concluded that that core strengthening, which involves top-down kinetic chain exercises, may assist male athletes in avoiding knee valgus alignment during side-step cutting.

Saad et al., (2018) reported that eight weeks of hip and quadriceps exercises (i.e., topdown kinetic chain) significantly reduced knee valgus angle during step tasks. A total of 40 female recreational athletes with PFPS were randomly assigned to hip-focused exercises, quadriceps-focused exercises, stretching exercises, and control (i.e., no intervention) groups. DKV was evaluated using a 3-D analysis of tibiofemoral flexion at $45^{\circ}$ during step tasks. The step-up task was associated with a higher DKV incidence rate because it is a challenging motion for individuals with PFPS (Saad et al., 2011). From the pre-test results, the valgus movement pattern appeared for $87.18 \%$ during step-up and $82.05 \%$ during step-down. However, these values decreased at the end of the intervention program to $66.67 \%$ in the hip-focused group and $48.72 \%$ in the quadriceps-focused group. Thus, the quadriceps-focused group showed a greater improvement than the hip-focused group in minimizing knee valgus.

Three other included studies found no significant changes in DKV following exercise intervention programs. Czasche et al. (2017) reported a change in the medial/lateral loading of the knee following eight weeks of lower limb strength training (i.e., top-down kinetic chain) despite a small non-statistically significant difference in the kinematics and GRF during drop landing. The study involved 16 untrained and healthy young students assigned to either control or intervention group. The intervention group received a leg strengthening exercise program for eight weeks while the control group continued their daily routines. The lack of changes in DKV could be due to the period of neural adaptation for strength training among untrained individuals. Previous research suggests that the motion of the knee valgus may be altered in highly untrained 
321 subjects who make significant gains in strength. For instance, Mascal, Landel \& Powers, (2003)

322 observed reduced knee valgus motion during step-down task in two untrained patients with

323 PFPS. The patient's strength increased by 50-110\% in specified muscle groups after resistance

324 training, indicating major muscle weakness prior to training (Mascal, Landel \& Powers, 2003).

325 Thus, for untrained participants, longer duration of lower limb strengthening program may be

326 needed for observable DKV kinematical changes.

327

328

McCurdy et al. (2012) found no significant difference in knee valgus angle during

329 bilateral $(60 \mathrm{~cm})$ and unilateral $(30 \mathrm{~cm})$ drop jumps between groups after eight weeks of resistance training. Twenty-nine young adult females with previous athletic experience were randomly assigned into either control or resistance training group. For two sessions a week, the experimental group engaged in progressive load of resistance training. Although multi joints weight-bearing training with free weights is assumed to be more sport-specific than resistance band training, it appears that neither form of training affect knee valgus angles during landing tasks (McCurdy et al., 2012). Even though they observed that 1RM squat increased by 19\%, athletes with previous resistance training experience will need more gains to dramatically change frontal plane kinematics during a drop jump task. Hence, the authors propose that long-term resistance training with a focus on increasing frontal plane intensity might be needed to change frontal plane kinematics.

Araújo et al. (2017) reported no significant differences in transverse plane knee kinematics during step-down task among women with DKV. The five exercises in the experimental group comprised hip and trunk (i.e., top-down kinetic chain) muscle strengthening exercises for three sessions per week. The load of the exercises was increased gradually over the eight-week intervention. Meanwhile, the control group did not receive any training program. The step-down task was used to evaluate the presence of DKV among the participants, which was confirmed when the tibial tuberosity shifted over the second toe on a vertical imaginary line. Despite the high training volume, the intervention was not adequate to alter any frontal and transverse kinematic variables. This may be caused by the lack of specificity of the prescribed exercises to the tested motions. Thus, they suggested a longer period of interventions and specific exercises to strengthen certain muscles such as hamstring and gastrocnemius, to produce more significant changes on the knee kinematics. They also addressed the need for additional functional training, such as real-time feedback training during the step-down task to help the participants inspect the changes in hip function. Despite a review from Dix et al., (2018) that showed the relationship between hip muscle strength and DKV, Araújo et al., (2017) did not report any significant improvement in DKV following eight-weeks of intervention. To the best of our knowledge, this study represented one of the negative findings about top-down kinetic chain exercises on DKV.

About half of the included studies showed high risk of bias in terms of randomization, allocation concealment, blinding of participants, study personnel and outcome assessors, which could have influenced their results. Also, the review was limited to the biomechanical knee outcomes thus, future studies should consider other factors such as hip and ankle biomechanics. 
361

\section{Conclusion}

363

364

365

366

367

368

369

370

371

372

373

374

375

376

377

378
In this review, we investigated the effects of exercise interventions, based on either topdown or bottom-up kinetic chains, on minimizing DKV during specific tasks. As DKV is one of the main factors that could increase the risk of lower limb injury, findings from this review highlighted the importance of prescribing exercise training program to improve DKV. Four studies (Barendrecht et al., 2011; Bell et al., 2013; Baldon et al., 2014; Thompson-Kolesar et al., 2017) found significant changes in knee valgus following a training program that combined both top-down and bottom-up kinetic chain exercises. Three studies (Sheerin, Hume, and Whattman, 2012; Saad et al., 2018; Jeong et al., 2021) discovered that top-down kinetic chain exercise intervention programs were also effective in reducing knee valgus. However, McCurdy et al., (2012), Czasche et al., (2017) and Araújo et al., (2017) did not detect any significant effects of the exercise intervention in minimizing DKV. Therefore, we concluded that a combination hip- and ankle- focused exercises and hip-focused (top-down kinetic chain) exercises only are more favorable than exercise program consisted of ankle-focused (bottom-up kinetic chain) exercises only. Apart from focusing on the load and volume of prescribed exercises, the specificity of exercises should also be emphasized. These findings might help the athletes and coaches to design appropriate exercise programs in reducing DKV.

\section{Acknowledgements}

We thank Li Shuoqi for his assistance in preparing the figures for the manuscript. This work was supported by the Malaysian Ministry of Higher Education (FRGS/1/2020/SKK06/USM/03/10). 


\section{References}

384

385

386

387

388

389

390

391

392

393

394

395

396

397

398

399

400

401

402

403

404

405

406

407

408

409

410

411

412

413

414

415

416

417

418

419

420

421

1. Araújo VL, Souza TR, Carvalhais VO, do C, Cruz AC, Fonseca ST. 2017. Effects of hip and trunk muscle strengthening on hip function and lower limb kinematics during step-down task. Clinical Biomechanics 44:28-35 DOI: 10.1016/j.clinbiomech.2017.02.012.

2. Baldon R, Silva RS, Piva SR, Uberti HH, Hayes WC. 2014. Effects of functional stabilization training on pain, function, and lower extremity biomechanics in women with patellofemoral pain: a randomized clinical trial. Journal of Orthopaedic \& Sports Physical Therapy 44(4):240-251. DOI: 10.2519/jospt.2014.4940. PMID: 24568258.

3. Barendrecht M, Lezeman HC, Duysens J, Smits-Engelsman BC. 2011. Neuromuscular training improves knee kinematics, in particular in valgus aligned adolescent team handball players of both sexes. The Journal of Strength \& Conditioning Research 25(3):575-84 DOI: 10.1519/JSC.0b013e3182023bc7. PMID: 21311350.

4. Bell DR, Oates DC, Clark MA, Padua DA. 2013. Two- and 3-dimensional knee valgus are reduced after an exercise intervention in young adults with demonstrable valgus during squatting. Journal of Athletic Training 48(4):442-449 DOI: 10.4085/1062-605048.3.16.

5. Bell DR, Padua DA, Clark MA. 2008. Muscle strength and flexibility characteristics of people displaying excessive medial knee displacement. Archives of Physical Medicine and Rehabilitation 89(7):1323-1328. DOI: 10.1016/j.apmr.2007.11.048.

6. Czasche MB, Goodwin JE, Bull AMJ, Cleather DJ. 2017. Effects of an 8-week strength training intervention on tibiofemoral joint loading during landing: A cohort study. BMJ Open Sport \& Exercise Medicine 4:1-8 DOI: 10.1136/bmjsem-2017-000273.

7. Dix J, Marsh S, Dingenen B, Malliaras P. 2018. The relationship between hip muscle strength and dynamic knee valgus in asymptomatic females: A systematic review. Physical Therapy in Sport 37(May):197-209 DOI: 10.1016/j.ptsp.2018.05.015.

8. Ford KR, Hegedus EJ, Zuk EF, Taylor JB. 2015. An evidence-based review of hipfocused neuromuscular exercise interventions to address dynamic lower extremity valgus. Open Access Journal of Sports Medicine 6:291-303 DOI: 10.2147/OAJSM.S72432.

9. Griffin LY, AlbohmMJ, Arendt EA, Bahr R, Beynnon BD, DemaioM, Dick RW, Engebretsen L, Garrett WE Jr, Hannafin JA, Hewett TE, Huston LJ, Ireland ML, Johnson RJ, Lephart S, Mandelbaum BR, Mann BJ, Marks PH, Marshall SW, Myklebust G, Noyes FR, Powers C, Shields C Jr, Shultz SJ, Silvers H, Slauterbeck J, Taylor DC, Teitz CC, Wojtys EM, Yu B. 2006. Understanding and preventing noncontact anterior cruciate ligament injuries: A review of the Hunt Valley II meeting, January 2005. The American Journal of Sports Medicine 34:1512-1532 DOI: 10.1177/0363546506286866.

10. Hewett TE, Lindenfeld TN, Riccobene JV, Noyes FR. 1999. The effect of neuromuscular training on the incidence of knee injury in female athletes. A prospective 
422

423

424

425

426

427

428

429

430

431

432

433

434

435

436

437

438

439

440

441

442

443

444

445

446

447

448

449

450

451

452

453

454

455

456

457

458

459

460

461

study. American Journal of Sports Medicine 27(6):699-706.

DOI:10.1177/03635465990270060301.

\section{Hewett TE, Myer GD, Ford KR, Heidt RS, Colosimo AJ, McLean SG, Succop P.} 2005. Biomechanical measures of neuromuscular control and valgus loading of the knee predict anterior cruciate ligament injury risk in female athletes: A prospective study. American Journal of Sports Medicine 33(4):492-501 DOI: 10.1177/0363546504269591.

12. Horsak B, Schwab C, Baca A, Greber-Platzer S, Kreissl A, Nehrer S, Keilani M, Crevenna R, Kranzl A, Wondrasch B. 2019. Effects of a lower extremity exercise program on gait biomechanics and clinical outcomes in children and adolescents with obesity: A randomized controlled trial. Gait Posture 70:122-129 DOI: 10.1016/j.gaitpost.2019.02.032. PMID: 30851623.

13. Huberti HH, Hayes WC. 1984. Patellofemoral contact pressures. The influence of Qangle and tendofemoral contact. The Journal of Bone and Joint Surgery 66:715-724. PMID: 6725318.

14. Ishida T, Yamanaka M, Takeda N, Aoki Y. 2014. Knee rotation associated with dynamic knee valgus and toe direction. The Knee 21(2):563-566. DOI: 10.1016/j.knee.2012.12.002.

15. Jamaludin NI, Sahabuddin FNA, Raja Ahmad Najib RKM, Shamshul Bahari MLH, Shaharudin S. 2020. Bottom-up kinetic chain in drop landing among university athletes with normal dynamic knee valgus. International Journal of Environmental Research and Public Health 17:4418 DOI: https://doi.org/10.3390/ijerph17124418.

16. Jeong J, Choi D, Shin C. 2020. Core strength training can alter neuromuscular and biomechanical risk factors for anterior cruciate ligament injury. The American Journal of Sports Medicine 49(1):183-192 DOI: 10.1177/0363546520972990

17. Kagaya Y, Fujii Y, Nishizono H. 2015. Association between hip abductor function, rear-foot dynamic alignment, and dynamic knee valgus during single-leg squats and drop landings. Journal of Sport and Health Science 4(2):182-187 DOI: 10.1016/j.jshs.2013.08.002.

18. Khamis S. Yizhar Z. 2007. Effect of feet hyperpronation on pelvic alignment in a standing position. Gait Posture 25: 127-134 DOI: 10.1016/j.gaitpost.2006.02.005.

19. Krosshaug T, Nakamae A, Boden B, Engebretsen L, Smith G, Slauterbeck J. Hewett TE, Bahr R. 2007. Mechanisms of Anterior Cruciate Ligament Injury in Basketball. The American Journal of Sports Medicine 35(3):359-367 DOI: 10.1177/0363546506293899.

20. Liberati A, Altman DG, Tetzlaff J, Mulrow C, Gotzsche PC, Ioannidis JP, Clarke M. Devereaux PJ. Kleijnen J. Moher D. 2009. The PRISMA statement for reporting systematic reviews and meta- analyses of studies that evaluate healthcare interventions: Explanation and elaboration. British Medical Journal 339:2700 DOI: 10.1016/j.jclinepi.2009.06.006.

21. Lima YL, Ferreira VMLM, de Paula Lima PO, Bezerra MA, de Oliveira RR, Almeida GPL. 2018. The association of ankle dorsiflexion and dynamic knee valgus: A 
462

463

464

465

466

467

468

469

470

471

472

473

474

475

476

477

478

479

480

481

482

483

484

485

486

487

488

489

490

491

492

493

494

495

496

497

498

499

systematic review and meta-analysis. Physical Therapy in Sport 29:61-69 DOI:

10.1016/j.ptsp.2017.07.003. PMID: 28974358.

22. Lopes TJA, Simic M, Myer GD, Ford KR, Hewett TE, Pappas E. 2018. The effects of injury prevention programs on the biomechanics of landing tasks: a systematic review with meta-analysis. The American Journal of Sports Medicine 46(6):1492-1499 DOI: $10.1177 / 0363546517716930$.

23. Mail M, Mohd Azhar N, Affandi N, Shaharudin S, Agrawal S, Chee L. 2019. Relationship between isokinetic leg strength and knee frontal plane projection angle during single leg squat among male junior athletes. Journal of Health and Translational Medicine 22(2):43-48 DOI: 10.22452/jummec.vol22no2.7.

24. Mascal C, Landel R, Powers C. 2003. Management of patellofemoral pain targeting hip, pelvis, and trunk muscle function: 2 case reports. Journal of Orthopaedic \& Sports Physical Therapy 33(11):647-660 DOI: 10.2519/jospt.2003.33.11.647.

25. McCurdy K, Walker J, Saxe J, Woods J. 2012. The effect of short-term resistance training on hip and knee kinematics during vertical drop jumps. Journal of Strength and Conditioning Research 26(5):1257-1264 DOI: 10.1519/jsc.0b013e31824f2386.

26. Mohd Azhar N, Affandi NF, Mail MSZ, Shaharudin S. 2019. The effects of foot position on lower extremity kinematics during single leg squat among adolescent male athletes. Journal of Taibah University Medical Sciences 14(4):343-349. DOI: 10.1016/j.jtumed.2019.06.007.

27. Myer GD, Ford KR, Di Stasi SL, Foss KD, Micheli LJ, Hewett TE. 2015. High knee abduction moments are common risk factors for patellofemoral pain (PFP) and anterior cruciate ligament (ACL) injury in girls: is PFP itself a predictor for subsequent ACL injury? British Journal of Sports Medicine 49(2):118-22. DOI: 10.1136/bjsports-2013092536. PMID: 24687011; PMCID: PMC4182160.

28. Nessler T, Denney L, Sampley J. 2017. ACL Injury Prevention: What does research tell us? Current Reviews in Musculoskeletal Medicine 10(3):281-288. DOI: 10.1007/s12178017-9416-5.

29. Noyes FR, Barber-Westin SD, Fleckenstein C, Walsh C, West J. 2005. The drop jump screening test, difference in lower limb control by gender and effect of neuromuscular training in female athletes. American Journal of Sports Medicine 33:378-387 DOI: $10.1177 / 0363546504266484$.

30. Olsen OE, Myklebust G, Engebretsen L, Bahr R. 2006. Injury pattern in youth team handball: A comparison of two prospective registration methods. Scandinavian Journal of Medicine \& Science in Sports 16:426-432 DOI: 10.1111/j.1600-0838.2005.00484.x.

31. Petersen W, Braun C, Bock W, Schmidt K, Weimann A, Drescher W, Eiling E, Stange R, Fuchs T, Hedderich J. Zantop T. 2005. A controlled prospective case control study of a prevention training program in female team handball players: the 
500

501

502

503

504

505

506

507

508

509

510

511

512

513

514

515

516

517

518

519

520

521

522

523

524

525

526

527

528

529

530

531

532

533

534

535

536

537

538

539

German experience. Archives of Orthopaedic and Trauma Surgery 125(9):614-621 DOI: 10.1007/s00402-005-0793-7. PMID: 15703919.

32. Powers CM. 2010. The influence of abnormal hip mechanics on knee injury: a biomechanical perspective. Journal of Orthopaedic \& Sports Physical Therapy 40(2), 42-51 DOI: 10.2519/jospt.2010.3337.

33. Saad, MC, Vasconcelos RA, Mancinelli L, Munno M, Liporaci RF, \& Grossi DB. 2018. Is hip strengthening the best treatment option for females with patellofemoral pain? A randomized controlled trial of three different types of exercises. Brazilian Journal of Physical Therapy 22(5):408-416 DOI: 10.1016/j.bjpt.2018.03.009.

34. Saad MC, Felício LR, Masullo CL, Liporaci RF, BevilaquaGrossi D. 2011. Analysis of the center of pressure displacement, ground reaction force and muscular activity during step exercises. Journal of Electromyography Kinesiology 21(Oct (5)):712-718 DOI: 10.1016/j.jelekin.2011.07.014.

35. Sheerin KR, Hume PA, Whatman C. 2012. Physical Therapy in Sport Effects of a lower limb functional exercise program aimed at minimizing knee valgus angle on running kinematics in youth athletes. Physical Therapy in Sport 13(4):250-254 DOI: 10.1016/j.ptsp.2012.01.003.

36. Snyder KR, Earl JE, O'Connor KM, Ebersole KT. 2009. Resistance training is accompanied by increases in hip strength and changes in lower extremity biomechanics during running. Clinical Biomechanics 24: 26-34 DOI: 10.1016/j.clinbiomech.2008.09.009.

37. Southgate D, Cleather D, Weinert-Aplin R, Bull A. 2012. The sensitivity of a lower limb model to axial rotation offsets and muscle bounds at the knee. Proceedings of The Institution of Mechanical Engineers, Part H: Journal of Engineering in Medicine 226(9):660-669 DOI: 10.1177/0954411912439284.

38. Thompson J, Tran A, Gatewood C, Shultz R, Silder A, Delp S, Dragoo J. 2016. Biomechanical effects of an injury prevention program in preadolescent female soccer athletes. The American Journal of Sports Medicine 45(2):294-301 DOI: $10.1177 / 0363546516669326$.

39. Thompson-Kolesar J, Gatewood C, Tran A, Silder A, Shultz R, Delp S, Dragoo J. 2017. Age influences biomechanical changes after participation in an anterior cruciate ligament injury prevention program. The American Journal of Sports Medicine 46(3): 598-606 DOI: 10.1177/0363546517744313

40. Verhagen E, van der Beek A, Twisk J, Bouter L, Bahr R, van Mechelen W. 2004. The Effect of a Proprioceptive Balance Board Training Program for the Prevention of Ankle Sprains. The American Journal of Sports Medicine 32(6): 1385-1393 DOI: $10.1177 / 0363546503262177$.

41. Willson JD, Ireland ML, Davis I. 2006. Core strength and lower extremity alignment during single leg squats. Medicine and Science in Sports and Exercise 38(5):945-952 DOI: 10.1249/01.mss.0000218140.05074.fa. 
42. Willson JD, Kernozek TW, Arendt RL, Reznichek DA, Scott Straker J. 2011.

541

542

Gluteal muscle activation during running in females with and without patellofemoral pain

543 syndrome. Clinical Biomechanics 26(7):735-740 DOI:

544

10.1016/j.clinbiomech.2011.02.012.

545

546

547

548 
Figure 1

PRISMA (Preferred Reporting Items for Systematic Reviews and Meta Analyses) flow chart of the included studies. 


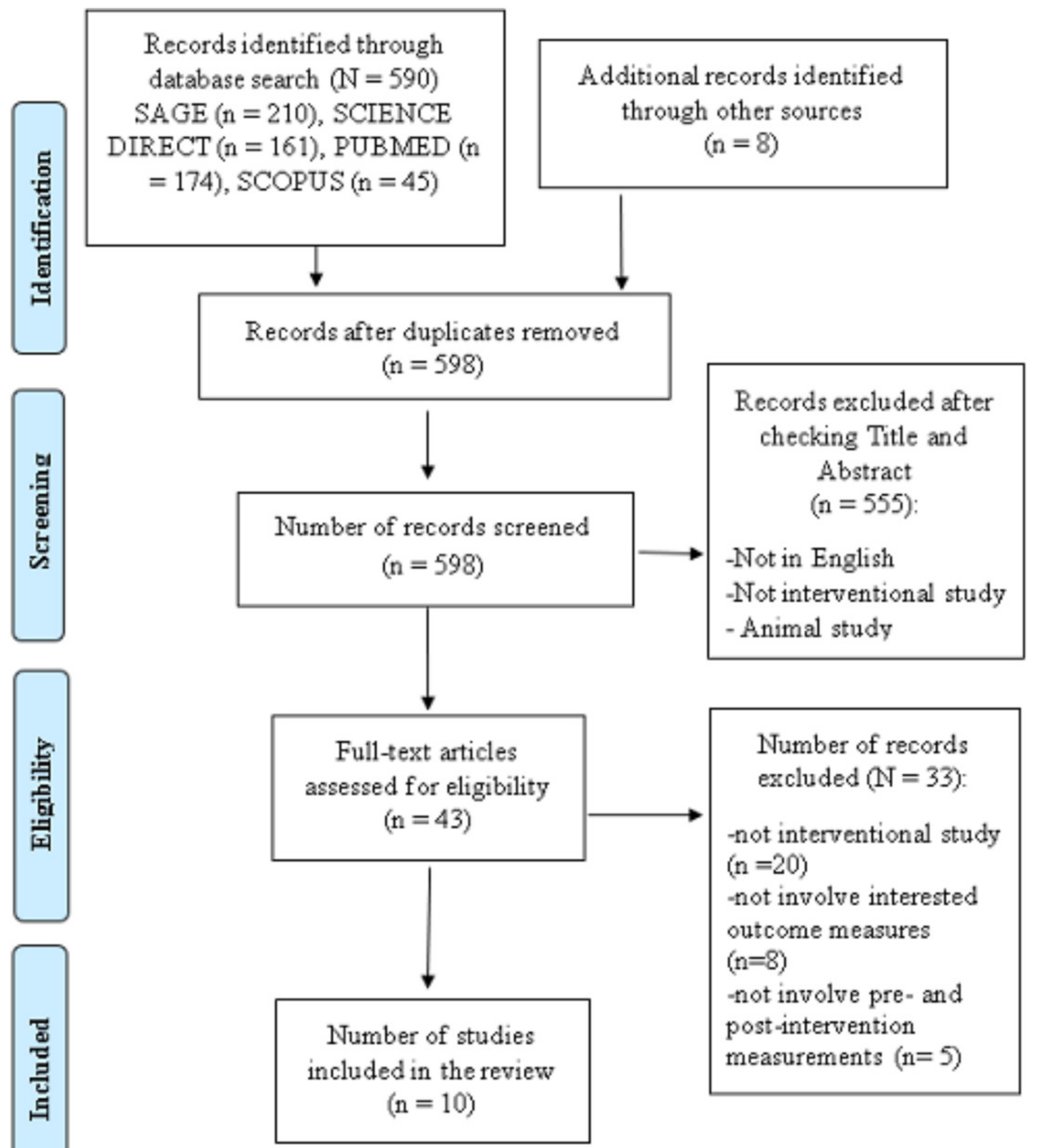


Figure 2

Risk of bias of the included studies.

The black fill indicates high risk of bias. The grey fill indicates unclear risk of bias. The white fill indicates low risk of bias.

Random sequence generation (selection bias)

Allocation concealment (selection bias)

Blinding of participants and personnel (performance bias)

Blinding of outcome assessment (detection bias)

Incomplete outcome data (attrition bias)

Selective reporting (reporting bias)

Other bias
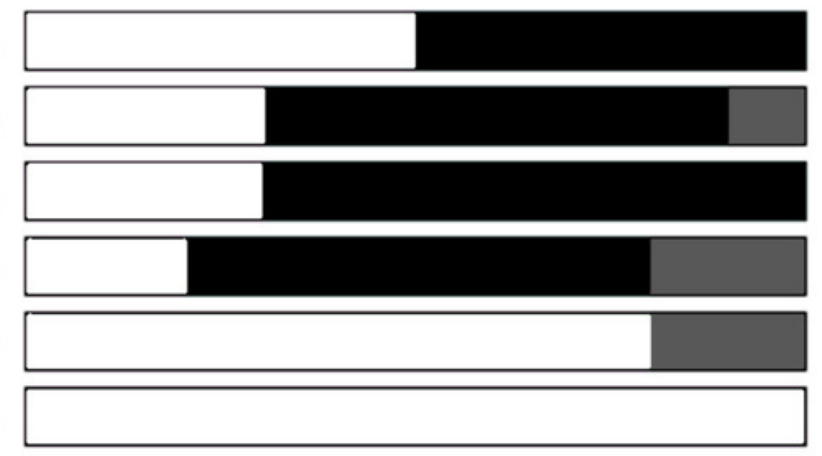

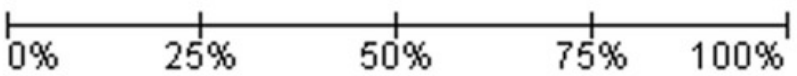




\section{Table 1 (on next page)}

Summary of the included studies 


\begin{tabular}{|c|c|c|c|c|c|c|}
\hline Study & $\begin{array}{l}\text { Participant's } \\
\text { characteristics }\end{array}$ & $\begin{array}{l}\text { Program } \\
\text { duration, } \\
\text { sessions } \\
\text { per week }\end{array}$ & \multicolumn{2}{|c|}{ Groups } & Task & $\begin{array}{l}\text { Outcome } \\
\text { Measures }\end{array}$ \\
\hline $\begin{array}{l}\text { Sheerin, } \\
\text { Hume \& } \\
\text { Whattman, } \\
2012\end{array}$ & $\begin{array}{l}\mathrm{n}=19 \\
(11 \text { male, } 8 \\
\text { female), } \\
9 \text { to } 14 \text { years } \\
\text { old (11.54 } \\
\pm 1.34 \text { years) } \\
\text { Healthy youth } \\
\text { athletes, } \\
\text { competitive } \\
\text { sports. } \\
\text { Presence of } \\
\text { DKV was } \\
\text { determined } \\
\text { based on knee } \\
\text { abduction } \\
\text { angle from } \\
\text { pre- } \\
\text { intervention }\end{array}$ & $\begin{array}{l}-8 \text { weeks } \\
-3 \text { times } \\
\text { per week }\end{array}$ & $\begin{array}{l}\text { Control group }(\mathrm{n}=10) \text { : } \\
\text { Open and closed kinetic chain } \\
\text { upper limb strengthening } \\
\text { exercises:- } \\
\text {-low pulley row and over- head } \\
\text { pull-down with a resistance } \\
\text { band, } \\
\text {-bicep curls } \\
\text {-lying chest press } \\
\text {-front and side shoulder raises } \\
\text {-overhead press with small } \\
\text { hand-weights } \\
\text {-triceps dips from a bench. }\end{array}$ & $\begin{array}{l}\text { Experimental group ( } \mathrm{n}=9 \text { ) } \\
\text { Similar training as control with } \\
\text { additional functional weight } \\
\text { bearing exercises:- } \\
\text {-side lying hip abduction } \\
\text {-double leg squats } \\
\text {-crab walking } \\
\text { - standing hip abduction } \\
\text {-single leg squat } \\
\text {-jump squats } \\
\text {-jumps squats with rotation } 90^{\circ} \\
\text { and } 180^{\circ} \\
\text {-Broad jump (forward deep } \\
\text { hold, single leg) } \\
\text {-double leg landing }\end{array}$ & $\begin{array}{l}\text { Treadmill-based } \\
\text { assessment of } \\
\text { running gait with } \\
\text { 3D analysis (while } \\
\text { wearing shoes) }\end{array}$ & $\begin{array}{l}\text { Differences in pre- } \\
\text { to post- } \\
\text { intervention } \\
\text { changes between } \\
\text { control and } \\
\text { experimental } \\
\text { groups: } \\
\text {-trivial for the } \\
\text { right knee }\left(-0.3^{\circ}\right) \text { - } \\
\text { large detrimental } \\
\text { increase in left } \\
\text { knee valgus angle } \\
\left(1.9^{\circ}\right)\end{array}$ \\
\hline $\begin{array}{l}\text { Baldon et } \\
\text { al., } 2014\end{array}$ & $\begin{array}{l}\mathrm{n}=31 \text { females } \\
18-30 \text { years } \\
\text { old } \\
(\mathrm{ST}=22.7 \pm 3.2 \\
\mathrm{FST}=\end{array}$ & $\begin{array}{l}\text { 8-weeks } \\
-3 \text { times } \\
\text { per week } \\
\text { Duration: } \\
\mathrm{ST}=\end{array}$ & $\begin{array}{l}\text { ST }(n=16) \\
\text {-Quadriceps and lateral } \\
\text { retinaculum, hamstrings, soleus, } \\
\text { gastrocnemius, and iliotibial } \\
\text { band stretches exercise } \\
\text {-straight leg raise in supine }\end{array}$ & $\begin{array}{l}\text { FST }(\mathrm{n}=15) \\
\text { Transversus abdominis and } \\
\text { multifidus muscle training } \\
\text { exercise } \\
\text {-lateral and ventral bridge } \\
\text {-trunk extension on the Swiss }\end{array}$ & $\begin{array}{l}\text { Single Leg Squat } \\
\text { test with depth } \\
\text { squat at least } 60^{\circ} \text { of } \\
\text { knee flexion }\end{array}$ & $\begin{array}{l}\text {-significant } \\
\text { reduction of knee } \\
\text { abduction moment } \\
\text { after 8-weeks of } \\
\text { intervention in } \\
\text { FST only. }\end{array}$ \\
\hline
\end{tabular}




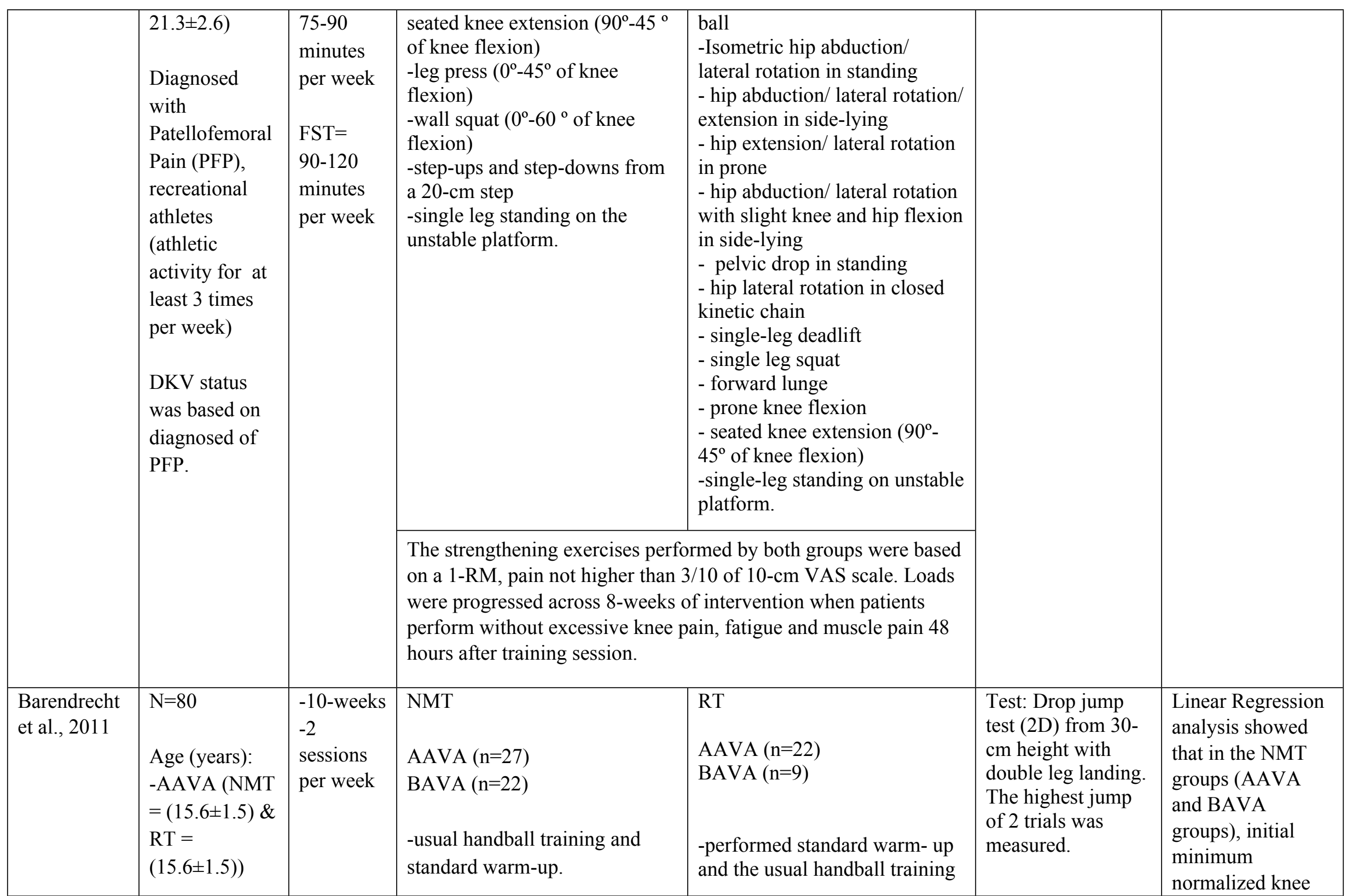




\begin{tabular}{|c|c|c|c|c|c|c|}
\hline & $\begin{array}{l}\text {-BAVA (NMT } \\
=(14.9 \pm 1.3) \& \\
\mathrm{RT}= \\
(15.2 \pm 1.3)) \\
\text { Handball } \\
\text { player (2 } \\
\text { female and } 2 \\
\text { male team) } \\
\text { The status of } \\
\text { DKV divided } \\
\text { into two } \\
\text { groups } \\
\text { (AAVA and } \\
\text { BAVA) based } \\
\text { on drop-jump } \\
\text { test. }\end{array}$ & & $\begin{array}{l}\text {-balance and coordination } \\
\text { exercises on a wobble board } \\
\text { and a mat } \\
\text {-strength and plyometric } \\
\text { exercises }\end{array}$ & only. & & $\begin{array}{l}\text { distance predicted } \\
59 \% \text { of the } \\
\text { variance in pre- to } \\
\text { post-test for knee } \\
\text { flexion angle. }\end{array}$ \\
\hline $\begin{array}{l}\text { Bell et al., } \\
2013\end{array}$ & $\begin{array}{l}\mathrm{N}=32 \\
\text { Volunteers } \\
\text { Age, (years)= } \\
(\text { Control } \\
\text { group=20.4 } \pm \\
2.9, \\
\text { intervention } \\
\text { group = 20.9 } \\
2.6), \\
\text { DKV were } \\
\text { screened in } \\
\text { double-leg } \\
\text { squats test. }\end{array}$ & $\begin{array}{l}-3 \text { weeks } \\
-2 \text { or } 3 \\
\text { sessions } \\
\text { per week }\end{array}$ & $\begin{array}{l}\text { Control Group }(\mathrm{n}=16) \\
\text {-No exercise intervention } \\
\text {-only perform functional test at } \\
\text { pre- and post-intervention. }\end{array}$ & $\begin{array}{l}\text { Intervention Group ( } \mathrm{n}=16) \\
\text {-Single limb Balance with } \\
\text { Squat (1-3 set x 10-15 rep) } \\
\text {-Single limb balance with squat } \\
\text { on unstable surface (2-3 set x } \\
10 \text { rep) } \\
\text {-Star Excursion Balance ( } 2 \text { to } 3 \\
\text { set x } 10 \text { rep) } \\
\text {-Star Excursion Balance on } \\
\text { unstable surface ( } 2 \text { to } 3 \text { set x } 10 \\
\text { rep) } \\
\text {-Hop to balance ( } 3 \text { set x } 10 \text { rep) }\end{array}$ & $\begin{array}{l}\text { Test: Double- } \\
\text { legged squat at } 90^{\circ} \\
\text { of knee flexion }\end{array}$ & $\begin{array}{l}\text { Only the } \\
\text { intervention group } \\
\text { showed a } \\
\text { significant } \\
\text { improvement on } \\
\text { the knee valgus by } \\
5^{\circ} \text { ( } 64 \% \text { reduction) } \\
\text { during half squat. }\end{array}$ \\
\hline
\end{tabular}




\begin{tabular}{|c|c|c|c|c|c|c|c|c|}
\hline $\begin{array}{l}\text { Czasche et } \\
\text { al., } 2017\end{array}$ & $\begin{array}{l}\mathrm{N}=16, \\
\text { Age (years)= } \\
\text { Control } \\
\text { group= } \\
(22.9 \pm 2.4) \& \\
\text { Intervention } \\
\text { group= } \\
(22.0 \pm 3.2) \\
\\
\text { Untrained } \\
\text { female and } \\
\text { only took part } \\
\text { in recreational } \\
\text { physical } \\
\text { activity at most } \\
4 \text { times per } \\
\text { week. } \\
\text { DKV was not } \\
\text { screened. }\end{array}$ & $\begin{array}{l}-8 \text { weeks } \\
-180 \\
\text { minutes } \\
\text { sessions } \\
\text { per week }\end{array}$ & \multicolumn{2}{|c|}{$\begin{array}{l}\text { Control group }(\mathrm{n}=8) \\
\text {-continue their routine } \\
\text { recreational activities }\end{array}$} & \multicolumn{2}{|c|}{$\begin{array}{l}\text { Intervention group ( } \mathrm{n}=8 \text { ) } \\
\text { Performed strength training } \\
\text { exercise:- } \\
\text {-split squat / bulgarian } \\
\text {-lunge } \\
\text {-step-up } \\
\text {-single leg bridge } \\
\text {-squats } \\
\text {-single leg good morning } \\
\text {-single leg hip thrust } \\
\text {-stiff leg deadlift } \\
\text { *Load were progressively } \\
\text { increased across } 8 \text { weeks based } \\
\text { on individual responses to } \\
\text { training (strength, experience } \\
\text { and motivation) } \\
\text {-sets, reps, rest and perceived } \\
\text { exertion were fixed. }\end{array}$} & $\begin{array}{l}\text { Test: bilateral } \\
\text { landings (BL) and } \\
\text { unilateral landings } \\
\text { (UL) both from } 30 \\
\mathrm{~cm} \text { platform. }\end{array}$ & $\begin{array}{l}\text { Kinematics in both } \\
\text { BL and UL in } \\
\text { intervention group } \\
\text { showed no } \\
\text { significant } \\
\text { differences from } \\
\text { pre- to post-test. }\end{array}$ \\
\hline $\begin{array}{l}\text { Saad et al., } \\
2018\end{array}$ & $\begin{array}{l}\mathrm{N}=40, \\
\text { Age (years)= } \\
\text { (Quadriceps } \\
(\mathrm{n}=23.2 \pm 2.53), \\
\mathrm{HIP} \\
(\mathrm{n}=22.5 \pm 1.08), \\
\text { Stretching } \\
(21.3 \pm 1.16) \\
\text { and Control } \\
(23.2 \pm 1.03)) \\
\text { Women with }\end{array}$ & $\begin{array}{l}-8 \text { weeks } \\
-2 \\
\text { sessions } \\
\text { per week }\end{array}$ & $\begin{array}{l}\text { QG }(\mathrm{n}=10) \\
\text { - quadriceps } \\
\text { strengthening } \\
\text { exercises. }\end{array}$ & $\begin{array}{l}\mathrm{HG}(\mathrm{n}=10) \\
\text { - hip } \\
\text { strengthening } \\
\text { exercises }\end{array}$ & $\begin{array}{l}\mathrm{SG}(\mathrm{n}=10) \\
\text {-Physical } \\
\text { therapists } \\
\text { monitored and } \\
\text { stabilized the } \\
\text { patients while } \\
\text { performing } \\
\text { stretching } \\
\text { exercises for } \\
\text { all muscles } \\
\text { involved in } \\
\text { knee and hip } \\
\text { stabilization. }\end{array}$ & $\begin{array}{l}\mathrm{CG}(\mathrm{n}=10) \\
- \text { Did not } \\
\text { receive any } \\
\text { kind of } \\
\text { treatment }\end{array}$ & $\begin{array}{l}\text { Test: Step-up and } \\
\text { down } \\
\text {-Dynamic valgus } \\
\text { were measured in } \\
\text { frontal plane at } 45^{\circ} \\
\text { tibiofemoral } \\
\text { flexion during step- } \\
\text { down task. }\end{array}$ & $\begin{array}{l}\text { At pre-test, } \\
\text { participants } \\
\text { showed valgus } \\
\text { movement } \\
\text { ( } 87.18 \% \text { during } \\
\text { step-up, and } \\
82.05 \% \text { during } \\
\text { step-down) These } \\
\text { values declined at } \\
\text { the end of } \\
\text { intervention } \\
\text { around } 66.67 \% \\
\text { and } 48.72 \% \\
\text { respectively in } \mathrm{HG}\end{array}$ \\
\hline
\end{tabular}




\begin{tabular}{|c|c|c|c|c|c|c|}
\hline & $\begin{array}{l}\text { PFP, } \\
\text { Participate in } \\
\text { aerobic or } \\
\text { athletic } \\
\text { activity at least } \\
3 \text { times per } \\
\text { week at least } \\
30 \text { min. } \\
\text { DKV status } \\
\text { was based on } \\
\text { diagnosed of } \\
\text { PFP. }\end{array}$ & & & & & and QG only. \\
\hline $\begin{array}{l}\text { Araujo et al., } \\
2017\end{array}$ & $\begin{array}{l}\mathrm{N}=34 \\
\text { Age (years): } \\
\text { (Experimental } \\
\text { group= } 22.41 \pm \\
3.81 ; \text { Control } \\
\text { group } \\
=21.71 \pm \\
2.08 \text { ) } \\
\text { Female } \\
\text { University } \\
\text { students. } \\
\text { DKV status: } \\
\text { present in both } \\
\text { groups. } \\
\text { Screened DKV } \\
\text { during } \\
\text { assessment of }\end{array}$ & $\begin{array}{l}\text {-8-week } \\
\text {-three } \\
\text { session } \\
\text { per week }\end{array}$ & $\begin{array}{l}\text { Control Group }(\mathrm{n}=17) \\
\text {-continued their usual routines } \\
\text { activities. }\end{array}$ & $\begin{array}{l}\text { Experimental Group }(\mathrm{n}=17) \\
\text {-Strengthening exercises: } \\
\text {-Hip lateral rotators } \\
\text {-Gluteus medium } \\
\text { Latissimus dorsi } \\
\text { Abdominal oblique and } \\
\text { quadratus lumborum } \\
\text {-Lateral rotation and extension } \\
\text { of the hip and trunk in closed } \\
\text { kinematic chain. } \\
1^{\text {st }} \text { to } 2^{\text {nd }} \text { weeks - minimal load } \\
3^{\text {rd }} \text { to } 4^{\text {th }} \text { weeks }-70-80 \% \text { of } \\
1 \text { RM } \\
5^{\text {th }} \text { to } 8^{\text {th }} \text { weeks }-90 \text {-100\% of } \\
1 \text { RM } \\
\text { Three sets of eight repetitions } \\
\text { with a one-minute interval } \\
\text { between sets. }\end{array}$ & $\begin{array}{l}\text { Test: step-down } \\
\text { from } 18 \mathrm{~cm} \text { step }\end{array}$ & $\begin{array}{l}\text { Knee kinematics } \\
\text { in transverse plane } \\
\text { during step-down } \\
\text { task was not } \\
\text { statistically } \\
\text { significant after } \\
\text { intervention in } \\
\text { both groups. }\end{array}$ \\
\hline
\end{tabular}




\begin{tabular}{|c|c|c|c|c|c|c|}
\hline & $\begin{array}{l}\text { step-down } \\
\text { task. }\end{array}$ & & & $\begin{array}{l}\text { *If the participant performed } \\
\text { three sets of nine repetitions on } \\
\text { two consecutive sessions, she } \\
\text { would perform the exercise } \\
\text { with the load increased by } 10 \% \\
\text { or } 5 \% \text {, in the consecutive } \\
\text { session. }\end{array}$ & & \\
\hline $\begin{array}{l}\text { Thompson- } \\
\text { Kolesar et } \\
\text { al., } 2017\end{array}$ & $\begin{array}{l}\mathrm{N}=94 \\
\text { Age (years): } \\
\text { Preadolescent } \\
\text { (intervention: } \\
11.8 \pm 0.8 ; \\
\text { control: } \\
11.2 \pm 0.6 \text { ) } \\
\text { Adolescent } \\
\text { (intervention: } \\
15.9 \pm 0.9 ; \\
\text { control: } \\
15.7 \pm 1.1 \text { ). } \\
\\
\text { Female soccer } \\
\text { athlete. } \\
\text { DKV status: } \\
\text { Preadolescent } \\
\text { displayed } \\
\text { greater knee } \\
\text { valgus than } \\
\text { adolescent } \\
\text { athlete. } \\
\text { Screened DKV }\end{array}$ & $\begin{array}{l}15 \\
\text { sessions } \\
-2 \\
\text { sessions } \\
\text { per week } \\
\\
-7-8 \\
\text { weeks }\end{array}$ & $\begin{array}{l}\text { Control group: } \\
\text { (Preadolescent }(n=23) \& \\
\text { adolescent athlete }(n=21)) \\
\text { Continued their daily routine. }\end{array}$ & $\begin{array}{l}\text { Intervention group: } \\
\text { (Preadolescent }(\mathrm{n}=28) \text { \& } \\
\text { adolescent athlete }(\mathrm{n}=22)) \\
\text { Each session lasted about } 25 \\
\text { minutes and served as a } \\
\text { replacement for each team's } \\
\text { standard warm-up prior to daily } \\
\text { practice. Exercises for core } \\
\text { strength, neuromuscular } \\
\text { control, balance, eccentric } \\
\text { hamstring training, plyometric, } \\
\text { and agility were included. }\end{array}$ & $\begin{array}{l}\text { Test: } \\
\text {-Single, double- } \\
\text { legged jump from } \\
30 \text { m box. } \\
\text {-Preplanned and } \\
\text { unanticipated } \\
\text { cutting. } \\
\text { *running } \\
\text { sidestepping cut off } \\
\text { the dominant limb } \\
\text { at } 45^{\circ} \text { from the line } \\
\text { approach. }\end{array}$ & $\begin{array}{l}\text { A significant } \\
\text { group effect in the } \\
\text { pre- to post change } \\
\text { for initial touch } \\
\text { knee valgus angle } \\
(\mathrm{P}=.004) \text { and peak } \\
\text { knee valgus } \\
\text { moment ( } \mathrm{P}=.011) \\
\text { during the double- } \\
\text { legged jump test } \\
\text { throughout the } \\
\text { intervention group. } \\
\text { Changes in initial } \\
\text { contact and peak } \\
\text { knee valgus angles } \\
\text { were not } \\
\text { significantly } \\
\text { different for all } \\
\text { activities in both } \\
\text { age groups. }\end{array}$ \\
\hline
\end{tabular}




\begin{tabular}{|c|c|c|c|c|c|c|}
\hline & $\begin{array}{l}\text { from the } \\
\text { baseline for all } \\
\text { tasks. }\end{array}$ & & & & & \\
\hline $\begin{array}{l}\text { Jeong et al., } \\
2021\end{array}$ & $\begin{array}{l}\mathrm{N}=48, \\
\text { Age (years)= } \\
\text { Control } \\
\text { group= }(23.1 \\
\pm 1.2) \& \\
\text { Intervention } \\
\text { group }= \\
(22.4 \pm 2.6) \\
\text { Male with } \\
\text { recreationally } \\
\text { active. } \\
\text { DKV was not } \\
\text { screened in } \\
\text { prior. }\end{array}$ & $\begin{array}{l}10 \text { weeks } \\
-2 / 3 \\
\text { sessions } \\
\text { per week }\end{array}$ & $\begin{array}{l}\text { Control group }(\mathrm{n}=16) \\
\text { Continued their usual routine. }\end{array}$ & $\begin{array}{l}\text { Intervention group ( } \mathrm{n}=32 \text { ) } \\
\text { Warm-up, 1.3-km jogging } \\
\text { Core training } \\
\text { 1. Leg raise } \\
\text { 2. Crunch } \\
\text { 3. Superman } \\
\text { 4. Plank hip twist } \\
\text { 5. Prone-plank } \\
\text { 6. Side-plank (both sides) } \\
\text { 7. Supine bridge } \\
\\
\text { Stretches } \\
\text { 1. Quadriceps } \\
\text { 2. Hamstring } \\
\text { 3. Calf stretches } \\
\text { 4. Latissimus dorsi } \\
\text { 5. Hip muscles } \\
\text { 6. Pectorals/biceps }\end{array}$ & $\begin{array}{l}\text { Side step cutting: } \\
\text {-Run } 3 \mathrm{~m} \text { at a } \\
\text { speed of } 3.5 \text { to } 4.0 \\
\mathrm{~m} / \mathrm{s} \text { before } \\
\text { contacting their } \\
\text { dominant foot on } \\
\text { the force plate and } \\
\text { then switching to } \\
\text { the opposite limb. } \\
\text { The line was } \\
\text { marked on the floor } \\
\text { to cut at } 45^{\circ} \text { angle } \\
\text { in the direction of } \\
\text { progression. }\end{array}$ & $\begin{array}{l}\text { After training, the } \\
\text { knee valgus angles } \\
\text { at initial contact } \\
\text { significantly } \\
\text { decreased by } 46 \% \text {, } \\
\text { compared with the } \\
\text { corresponding } \\
\text { values in pre } \\
\text { training (P =.038) } \\
\text { No significant } \\
\text { differences were } \\
\text { observed in the } \\
\text { knee valgus for } \\
\text { control group. }\end{array}$ \\
\hline $\begin{array}{l}\text { McCurdy et } \\
\text { al., } 2012\end{array}$ & $\begin{array}{l}\mathrm{N}=29, \\
\text { Age (years)= } \\
(21.04 \pm 1.83) \\
\text { Female with } \\
\text { previous high } \\
\text { school athletic } \\
\text { experience. } \\
\text { DKV was not } \\
\text { screened. }\end{array}$ & $\begin{array}{l}8 \text { weeks } \\
-2 \\
\text { sessions } \\
\text { per week }\end{array}$ & $\begin{array}{l}\text { Control group }(\mathrm{n}=16) \\
\text {-Did not provide any training. } \\
\text {-continued their routine as } \\
\text { usual. }\end{array}$ & $\begin{array}{l}\text { Experimental group }(\mathrm{n}=13) \\
\text { Bilateral squat } \\
\text { Lunge } \\
\text { Step up } \\
\text { Romanian deadlift } \\
\text { Unilateral squat } \\
\text {-A linear periodized program } \\
\text { was applied by increasing } 5 \% \\
\text { each week while the volume } \\
\text { decreased. } \\
\text {-Progression was adopted by } \\
\text { including bilateral squat and }\end{array}$ & $\begin{array}{l}\text { Drop jump task: } \\
\text {-Jump from } 60 \mathrm{~cm} \\
\text { for bilateral jumps } \\
\text {-Jump from } 30 \mathrm{~cm} \\
\text { box for unilateral } \\
\text { jumps }\end{array}$ & $\begin{array}{l}\text { No significant } \\
\text { main effects for } \\
\text { training groups } \\
\text { (control vs. } \\
\text { resistance trained) } \\
\text { or trials (pretest } \\
\text { vs. posttest). } \\
\text { No significant } \\
\text { difference between } \\
\text { pre- and post-test } \\
\text { knee flexion } \\
\text { values in the } \\
\text { control group for }\end{array}$ \\
\hline
\end{tabular}




\begin{tabular}{|l|l|l|l|l|}
\hline & & & $\begin{array}{l}\text { Romanian deadlift in the first } \\
\text { weeks and 8-week period while } \\
\text { unilateral exercises were added } \\
\text { in the mid-training period. }\end{array}$ & $\begin{array}{l}\text { the unilateral } \\
\text { jump, but there } \\
\text { was a significant } \\
\text { decrease from } \\
\text { pretest }(82.4 \pm 3.9) \\
\text { to posttest }(69.6 \pm \\
5.2) \text { values for the } \\
\text { bilateral jump. }\end{array}$ \\
\hline
\end{tabular}

Abbreviation: Dynamic knee valgus- DKV; Functional Stabilization Training- FST; Standard Training- ST; Patellofemoral pain PFP; Above-Average Valgus Aligned -AAVA; Below Average Valgus Aligned - BAVA; Neuromuscular training- NMT; Regular 5 training- RT, Control Group- CG; Quadriceps Strengthening Group- QG; HIP Strengthening Group- HG; Stretching Group- SG; 6 Exercise Program Group- EP; Repetition maximum- RM. 